УДК $781+784.3$

\title{
Ван Te
}

\section{НАЦИОНАЛЬНАЯ ИСПОЛНИТЕЛЬСКАЯ ТРАДИЦИЯ КАК ОСНОВА ОПЕРНОГО ТВОРЧЕСТВА ДЖ. ВЕРДИ}

В статье исследуются национальные и исполнительские истоки с выделением вопросов истории и теории вокального исполнительства и вокальной педагогики как основы оперной поэтики Дж. Верди. Вердиевская музыкальная драма предстает как итог развития оперного искусства Италии ХІХ века, что обосновывает и формирует новую исполнительскую школу, требуюшую от певцов дополнительных профессиональных качеств.

Ключевые слова: опера, вердиевская музыкальная драма, исполнительская школа, вокальная педагогика, исполнительский стиль.

Обращение к национально-исполнительским истокам оперной поэтики Дж. Верди заставляет выходить за пределы исторических музыковедческих работ, обращаться к исследованиям, посвященным проблемам истории, теории и методики вокального исполнительства и вокальной педагогики [1; 4-6; 10]. Обобщение ряда положений данных исследований позволяет предложить ряд констатаций, что и является залогом актуальности и востребованности затронутого в статье исследовательского направления.

Формированию национальной итальянской вокальной школы, которая в большей степени связана с исторически сложившемся стилем bel canto, предшествовал длительный путь развития, завершившийся рождением нового жанра - оперы, впитавшего все лучшее, что накопилось за века в народном, церковном и светском музыкальном искусстве. Гибкость мелодии, динамическое и ритмическое разнообразие народных песен (плач, тарантелла, сицилиана, лирические) предвосхитили вокальную основу итальянского академического пения. Нельзя не учитывать и способствующие пению фонетические особенности итальянского языка, с неизменностью звучания гласных относительно любых соседних согласных, с частым удвоением сонорных согласных, перед которыми звучание гласных требует высоко поднятого неба, с отсутствием сложных звукосочетаний, активностью артикуляции.

Опера конца XVIII века переживает сильнейший кризис, ибо полностью порывает с реалистическими принципами Монтеверди, Кавалли, Чести, утрачивает драматургическую цельность, превращается 
в своеобразный конкурс певцов-виртуозов-импровизаторов. Кризис коснулся и исполнительского искусства: смысловая сторона, выразительность исполнения были оттеснены на второй план; блестящая вокальная техника становится самоцелью. Искусство импровизации теряет свою художественную ценность. В 30-х годах XVIII века комические элементы, включаемые в оперы, перерастают в самостоятельный жанр, получивший название оперы buffa (комическая). Первой оперой buffa стала «Служанка-госпожа» Джованни Баттиста Перголези, которая первоначально являлась вставкой в опере-seria «Гордый пленник». Перед исполнителями этого жанра были поставлены новые задачи: простота и органичность сценического поведения, широкое использование различных выразительных средств, умелое применение динамической и тембровой нюансировки, передающей перемену чувств и настроений героев. Опера buffa, прежде всего, живой и веселый театральный спектакль, где сценическое действие и взаимоотношения персонажей поставлены во главу угла. Тем не менее, в них сохраняется самый ценный элемент оперы-seria - яркие, развернутые и технически сложные арии. Демократичность сюжета, особенность трактовки партий действующих лиц вызвали к жизни новые выразительные средства, основанные на органичности сценического поведения - мимике, жесте, то есть целого комплекса музыкально-сценических выразительных средств. Появляется плеяда превосходных комических артистов, наделенных вокально-техническим мастерством. К концу XVIII века произошла историческая победа теноров над певцами-кастратами. В операх seria и операх buffa тенорами исполнялись второстепенные роли - пажей, пастухов и т. д. На премьере оперы Доменико Чимарозы «Тайный брак» (1792) с большим успехом пел тенор Джузеппе Виганони. С этого времени мужские партии стали исполняться тенорами, а с появлением таких мастеров, как Андреа Нодзари, Джакомо, Давид, певцы-кастраты были вытеснены с оперной сцены. Завершение нового исполнительского стиля оперы buffa происходит уже в XIX веке и связано с именем Джоаккино Россини.

Центрами вокального обучения в Италии XVII-XVIII веков являлись консерватории, представлявшие собой закрытые учебные заведения, в которых воспитывались певцы с раннего детского возраста. Первоначально консерваториями назывались приюты для сирот, где детей обучали ремеслам. В XVII веке в приютах было введено преподавание музыки, которое впоследствии заняло основное место в об- 
учении и продолжалось 8-10 лет. Вокальное образование начиналось с детства, с шести-семилетнего возраста. Окончательное формирование певца заканчивалось примерно к 17 годам. Программы консерваторий отличались необычайной насыщенностью и предполагали воспитание широко образованного музыканта, владеющего основами композиции, несколькими музыкальными инструментами, способного справляться с вокально-техническими трудностями, освоившего навыки преподавания вокала. В основе обучения пению лежал эмпирический метод: метод показа, подражания. Следовательно, учителем пения мог быть только певец. Однако требования к нему этим не ограничивались. Как правило, учитель пения был человеком широкой эрудиции и больших творческих возможностей.

Первые музыкально-сценические произведения (dramma per musica) носили в значительной мере речевой характер. Спокойная, ненапряженная вокальная речь предполагала использование умеренной громкости, отсутствие резких динамических изменений; не требовалась и продолжительность фонаций (вокальные партии ограничены октавным диапазоном), мелодические построения были короткие, а интервалы узкие. Отсюда вполне естественно использование речевого дыхания. Позднее, в период популярности оперных произведений Монтеверди, Кавалли, Чести, Скарлатти, широко распространенное искусство филировки (как одно из определяющих выразительных средств), а также необходимость петь продолжительные музыкальные фразы потребовали организации не речевого, а специфического певческого дыхания. Вот почему П. Ф. Този советует набирать его больше, чем обычно, заботясь при этом, чтобы грудь не уставала. Он же предупреждает о необходимости экономного распределения набранного количества воздуха. А Манчини не только рекомендует легко набирать и экономить набранное количество воздуха, но и внимательно относиться к певческому выдоху, от которого, по его мнению, зависят некоторые существенные качества голоса. Манчини уже дает более развернутые советы, говоря о необходимости сохранить дыхание с такой экономией, чтобы приучить аппарат регулировать, умерять и сдерживать голос. Впервые появляется понятие «искусство дыхания». К филировке, по мнению автора, нельзя приступить прежде, чем освоено искусство сохранять, задерживать и усиливать дыхание. Генрих Фердинанд Манштейн подводит своего рода итог развитию педагогической мысли о характере певческого дыхания и дает исчерпывающую формулировку: дыхание должно орга- 
низовываться таким образом, чтобы экскурсировала грудная клетка (во время вдоха расширяется и поднимается, во время фонационного выдоха незаметно возвращается в исходное положение). Подчеркивая необходимость специальной тренировки, Манштейн дает практические советы: пользоваться каждой паузой для добора воздуха, запасаться большим его количеством перед длительной музыкальной фразой или пассажем и т. д. Подчеркивая специфичность певческого дыхания, Манштейн называет его «хитростью в пении» [1].

B середине XIX века в оперном искусстве Италии выдвигается могучая фигура Джузеппе Верди. Он оставил миру 26 опер, из которых первая «Оберто граф сан Бонифаччо» была создана 25-летним композитором, а последняя - «Фальстаф» - прославленным 80-летним мастером. Все его оперы были поставлены в миланском театре Ла Скала. В творчестве Верди сфокусированы достижения предшественников. Он творил в период мощного революционного подъема и в его сочинениях отразились патриотические настроения итальянского народа, стремление к независимости, поэтому в народе Верди называли Маэстро итальянской революции. Композитор предъявляет повышенные требования к либретто, считая необходимыми контрастные сопоставления, чередование низменного и возвышенного, героического и будничного. Его творчество отличает шекспировский подход к трактовке сюжета, основой которого должна быть правда жизни. Отсюда установка: опера немыслима без конфликтных противоречий, без резко заостренных антитез, напряжения страстей, которые порождали бы музыкальное динамичное действие. Верди всегда берет на себя ответственность не только за музыку, но и за сюжет, либретто, сценическое решение и оформление. Для создания музыкальной драмы необходимо найти синтез музыки, слова, сценического воплощения, добиться всестороннего эмоционального и интеллектуального воздействия на слушателя. Верди выдвигает новые серьезные требования к оперным певцам. Так, в поисках певицы на роль леди Макбет Верди отклонил предложение дирекции пригласить на эту роль Эужению Тадолини, так как он считал, что леди Макбет должна быть с дьявольским голосом и дьявольской внешностью, а не ангел с ангельским голосом [7].

Основным фактором в опере Дж. Верди считает мелодию, которая должна быть связана с драматической правдой, с глубоким проникновением в сущность характера [11]. С этих позиций он критикует предшественников, в частности Россини, говоря, что мелодии не де- 
лают из гамм, трелей и группетто. В сочинениях Верди колоратура и сложные пассажи практически отсутствуют, вокальные же партии требуют более насыщенного звучания, хорошего звукового посыла. Значительно расширяется верхний участок диапазона мужского голоса, кульминация переносится наверх, и оперная драматургия полностью исключает светлое фальцетное звучание, замененное так называемым прикрытым звуком. Контрастное сопоставление ситуаций, изменение психологических состояний ведет, естественно, к широкому использованию динамической нюансировки. Высокая тесситура баритональных партий, оправданная необходимостью передать большую степень эмоционального накала, психологическую напряженность, вынуждает певцов находить соответствующие приспособления в работе голосового аппарата. Не случайно появляется новая классификация - «вердиевский баритон». Этому типу голоса Верди поручает героические партии. Первым певцом такого типа был Дж. Ронкони - исполнитель партии Навуходоносора в одноименной опере. Одной из особенностей вердиевских арий является включение речитативных декламационных элементов в кантиленную линию. Это драматизирует арию и усложняет задачу вокалиста, от которого требуется гибкий переход от одной манеры голосообразования к другой [2]. По мере роста профессионализма Верди все более требовательно относился к сценическому воплощению своих опер. Создание музыкальной драмы, изменение характера вокальных партий вызвали необходимость активного вмешательства композитора в работу актеров над художественным образом. Первые репетиции, на которых Верди был дирижером, режиссером-постановщиком и педагогом, вызвали негативную реакцию артистов. Артисты доказывали невозможность исполнения вокальных партий, их недопустимую сложность, нарушающую естественность пения. Широко известен случай, когда знаменитому певцу тенору Франческо Таманьо, обладателю огромного по силе и диапазону голоса с особенно яркими высокими нотами, не удавалась заключительная сцена Отелло, и Верди стал показывать, как надо ее провести. И когда старый маэстро упал у ложа мертвой Дездемоны и скатился с возвышения, на котором оно было установлено, присутствующая на репетиции публика замерла: все были уверены, что маэстро не выдержал огромного эмоционального напряжения. Вздох облегчения вырвался у слушателей, когда Верди поднялся и спокойно сказал, что именно так он представляет себе сцену гибели Отелло [9]. 
Таким образом, вердиевская музыкальная драма, как итог развития оперного искусства Италии XIX века, вызвала к жизни новую исполнительскую школу, потребовала от певцов дополнительных профессиональных качеств: сочетания вокального и актерского мастерства, широкого звуковысотного диапазона, ровности и однородности звучания голоса, создания смешанного регистра и прикрытия верхнего участка диапазона мужского голоса [2].

Таким образом, изменение исполнительского стиля, новые задачи, стоящие перед певцами-исполнителями вокальных партий в операх Дж. Россини, В. Беллини, Г. Доницетти и Дж. Верди, привели к существенной коррекции вокального исполнительства. Старая методика воспитания не могла уже обеспечить необходимых профессиональных качеств певцов XIX века. Накопление исполнительского опыта позволило сформировать новую педагогическую методику. В то же время Франческо Ламперти - наиболее крупный педагог, воспитавший блистательную плеяду певцов, никогда не был профессиональным певцом. Музыкант широкого профиля (органист, директор оперного театра), он прославился как вокальный педагог, с 1850 года работая профессором пения в Миланской консерватории. Ламперти оставил ряд теоретических работ: «Теоретически-практическое руководство для изучения пения», «Первые уроки вокала» и развернутый труд, переведенный в 1892 году на русский язык, «Искусство пения» [2; 4].

Итак, к концу XIX века складывается понятие об оперном мастерстве как о целостном явлении, органически сочетающем вокальные и актерские навыки. Поэтому и вердиевская драма, достигшая вершин вокально-драматической выразительности, требовала от певцов иного отношения к оперному тексту, в том числе большего напряжения голосового аппарата, большей насыщенности, мощи, красочности звука, особенно в верхнем регистре, на который легла основная нагрузка в кульминационных моментах не только в арии, но и в речитативах (что вызвало особое недовольство у любителей плавной, текучей мелодии), требовала энергии, выразительной декламации, порывистости, темперамента [2; 9]. Эта тенденция еще более усилилась с возникновением нового стилистического направления, получившего название «веризм» (от итал. «vero» - правда, истина), духовным отцом которого был Эмиль Золя. Появились молодые композиторы, творчество которых повлияло на исполнительский стиль. Известный литератор - глава итальянского веризма Джованни Вер- 
га оказал решающее влияние на развитие оперного искусства своей страны. На смену историческим сюжетам и героям большой общечеловеческой значимости приходит человек из народа, но наделенный сильными чувствами и страстями. Вместо грандиозных спектаклей рождается одноактная опера-новелла. В 1899 году в Милане был объявлен конкурс на лучшую одноактную оперу. Первую премию получил П. Масканьи за оперу «Сельская честь». В 1892 году в миланском театре Даль Верме прошла премьера второй веристской оперы «Паяцы» Р. Леонкавалло.

Большим успехом пользовалась первая исполнительница партии Сантуццы Джема Беллинчони. В анналы истории вокального исполнительства вписаны имена теноров Роберто Станьо (первого Туриду) и Джузеппе Боргатти - интерпретаторов творчества композиторов-веристов Масканьи, Леонкавалло, Чилеа, Джордано. Особая страница в истории оперного искусства принадлежит творчеству Джакомо Пуччини - композитора, создавшего свой ярко индивидуальный почерк, во многом отличающийся от стиля современников. Его творчество оказало существенное влияние на развитие оперного композиторского и исполнительского искусства XX века. Оперы Дж. Пуччини привлекали ведущих исполнителей не только Италии, но и других стран. Им импонировала мелодическая щедрость, глубокая музыкально-психологическая характеристика героев, возможность продемонстрировать свое вокальное мастерство, а главное - с помощью художественного интонирования и актерского мастерства создавать убедительные образы героев оперы.

Творчество талантливых исполнителей смягчало веристский надрыв и способствовало формированию «верди-веристсткого» стиля. Ярким представителем нового «верди-веристского» исполнительского стиля стал Энрико Карузо. Вершиной его искусства была роль Канио («Паяцы»). Сочетание необычайно мощного голоса, пленительного тембра, истиной эмоциональности, порывистости и нежности делало исполнение Карузо неповторимым. Современники Карузо отмечали его удивительную способность менять тембр в зависимости от характера вокальной партии.

Одним из лучших певцов верди-веристского направления был также Титта Руффо - обладатель редкого голоса широчайшего диапазона, силы и исключительной красоты тембра. Современники отмечали его способность использовать различные краски, делавшие его голос то мягким и бархатистым, то резким и металлическим 
(звонким, холодным). В репертуар знаменитого драматического баритона входило более шестидесяти произведений. Наиболее любимыми были партии в операх Верди и композиторов-веристов. Более тридцати произведений, исполненных Титта Руффо, записаны на пластинки и дают возможность в полной мере оценить искусство замечательного певца.

Обсуждение предпосылок формирования национальных черт оперного стиля Верди останется неполным, если не сравнить его творческий метод с некоторыми принципами творчества Р. Вагнера. Как известно, Рихард Вагнер и Джузеппе Верди ровесники - родились в один год (1813), и оба они стали национальной гордостью своих стран: Вагнер - Германии, Верди - Италии. Но именно поэтому их творческие установки принципиально различны. Конечно, у этих двух великих композиторов есть и сходство: оба вошли в историю как оперные реформаторы, хотя Верди, как ни странно, в меньшей степени. Такая полярность мастеров начинается с разности их мировоззрений, социально-эстетических и художественных идеалов [3].

Эпоха, породившая Верди, - эпоха национальных войн и буржуазных революций, эпоха национально-освободительного движения в Италии за независимость и политическую свободу. Верди принимал участие в этой борьбе как художник, трибун и певец своего народа, глашатай его чувств и стремлений. И борясь за свободу своего искусства, за его жизненность, правдивость и простоту, Верди черпал силы из народного источника, из итальянской песни и превратился в подлинного национального художника, прославившего себя и свою страну. Отсюда такая важнейшая черта стиля Верди как демократичность.

В 60-е годы Верди знакомится с принципами оперной реформы Вагнера и с его творчеством. Он считает, что итальянские композиторы не дают ничего художественно значительного, что наиболее талантливые из них, как Бойто, проявляют интерес к «вредным» влияниям. Верди чувствует себя единственным и самым ответственным из композиторов, ответственным за будущее итальянской национальной оперы. 60-е годы - это годы упорной подготовки композитора к борьбе, его вооружения новейшими достижениями музыкально-драматургической техники. «Аида» и «Отелло» - итог этой подготовки. В связи с общей идейной эволюцией Верди возрос интерес композитора к обличению жизненного зла: с ним связаны жрецы в «Аиде», инквизиция в «Дон Карлосе», Яго в «Отелло». Силы зла и жестокости 
Верди показывает типичными для себя средствами: одноголосная мелодия, лишенная сопровождения, движется размеренными, прямолинейными шагами, часто унисоном, порой развивается канонически, производя впечатление неумолимо надвигающийся силы (Хор жрецов).

Наиболее ранняя реформаторская опера Верди - «Дон Карлос». Она подготавливает все последующее его творчество, будучи завершенной психологической драмой. Верди уже не делит оперу на номера, придавая ей, подобно Вагнеру, сквозное развитие. Продолжает реформаторские находки Верди опера «Аида». Здесь композитор уже широко пользуется лейтмотивами, но не пропитывает ими всю музыкальную ткань, а применяет их как характеристики персонажей, звучащие при появлении или значении в данный момент образа, к которому они относятся [8].

Только Верди из всех европейских композиторов смог, опираясь на крепкие основы классической национальной музыкально-драматической культуры, противопоставить нечто реальное и положительное реформе Вагнера. Верди тоже создает оперу сквозного развития, но сохраняет номер как опору драматургии: он имеет разомкнутую форму и не останавливает действие, что претворилось в «Аиде» в полном объеме. В данной опере Верди сочетал лучшие черты трех оперных школ, сохранив при этом ее национальную основу. В «Отелло» Верди нашел идеальное соотношение между речитативно-декламационным и песенно-ариозным началом. Поэтому так ограничены в опере переходы от речитативных форм к ариозным. Но мелодическая щедрость Верди не иссякла, он верен народно-песенным истокам. В поздних операх Верди, как и Вагнер, отказывается от увертюры и использует оркестровое вступление. Но у Вагнера подобное вступление не конфликтно представляет один образ, как во вступлении к «Золоту Рейна», а у Верди, если взять «Аиду», ярок контраст между лейтмотивом Аиды и темой жрецов, сливающихся потом в контрапункте. Вагнер полностью отвергал хоры, Верди же от хоров не стал отказываться и широко их использует в той же «Аиде», что не отменяет его интереса к ансамблю, например, к септету в «Отелло» или к свободной монологической форме весьма родственной вагнеровским декламационным построениям (Аида, Яго).

Гармония Вагнера достигла вершины своего развития в «Тристане и Изольде», но идея вуалирования (избежания) тоники проявила себя уже в «Лоэнгрине». По мнению Вагнера, тональная устойчивость 
останавливает, дробит музыку - отсюда вагнеровская «бесконечная» мелодия. Верди же долго не мог отказаться от T-S-D отношений, квадратности и периодичности. Но в поздний период творчества его гармонический язык стал заметно более гибким и ярким, тональное движение - более разнообразным. Так, в «Аиде» Верди чутко воссоздает характерные ладовые особенности ориентальной музыки, используя пониженные II и VI ступени (молитва Великой жрицы). Колорит создается и средствами тембровой выразительности: в картине ночи на берегу Нила (начало III акта) Верди использует флейты с засурдиненными скрипками, пиццикато альтов и флажолетами виолончелей. Становясь колоритнее и разнообразнее, начиная с 50-х годов оркестр Верди не потерял, однако, своих индивидуальных качеств: сочного и мужественного звучания, «чистых» тембров, ярких сопоставлений контрастирующих групп, светлого и прозрачного колорита, мощной динамики.

Таким образом, творчество Верди идет по собственному пути, но и частично приводит к родственным Вагнеру идеям, которые можно считать общим велением времени и выражением общей жанровоисторической тенденции в эволюции оперной поэтики. Своеобразие оперного метода Верди, обусловленное его эстетическими позициями, но непосредственно проявляющееся на уровне музыкальной драматургии, определяется именно как национальное - в контексте специфических свойств итальянского романтизма.

\section{СПИСОК ЛИТЕРАТУРЫ}

1. Багадуров В. Очерки по истории вокальной педагогики / В. Багадуров. - М. : Музгиз, 1956. -268 с.

2. Вильнер Н. Как петь Верди? / Н. Вильнер, М. Дворкина // Советская музыка. - 1989. - С. 44-49.

3. Галь Г. Брамс. Вагнер. Верди: три мастера - три мифа / Г. Галь ; [пер. с нем.]. - М. : Радуга. 1986. - 480 с.

4. Гнидь Б. Історія вокального мистецтва : [підручник] / Б. Гнидь. К. : НМАУ ім. П. І. Чайковського, 1997. - 320 с.

5. Дмитриев Л. Основы вокальной методики / Л. Дмитриев. - М. : Музыка, 1968. $-675 \mathrm{c}$.

6. Драч И. Художественная выразительность итальянского бельканто как системы музыкального интонирования / И. Драч // Из истории национальных оперных школ. - К., 1988. - С. 64-76.

7. Нюрнберг М. В. Джузеппе Верди. 1813-1901. Краткий очерк жизни и творчества / М. В. Нюрнберг. - Л. : Музыка, 1968. - 133 с. 
8. Соловцова Л. «Аида» Джузеппе Верди. - М. : Музгиз, 1962. - 72 с.

9. Соловцова Л. Джузеппе Верди / Л. Соловцова. - [4 изд.]. - М. : Музыка, 1986. -399 с.

10. Стахевич А. Вокальное искусство Западной Европы: творчество, исполнительство, педагогика: исследование / А. Стахевич. - К. : НМАУ ім. П. І. Чайковского, 1997. - 272 с.

11. Шавердян Р. Мелодика Верди / Р. Шавердян // Советская музыка. 1960. - № 6. - С. 94-101.

Ван Те. Національна виконавська традиція як основа оперної творчості Дж. Верді. У статті досліджуються національні та виконавські витоки з виділенням питань історії та теорії вокального виконавства і вокальної педагогіки як основи оперної поетики Дж. Верді. Вердіївська музична драма постає як підсумок розвитку оперного мистецтва Італії XIX століття, що обгрунтовує і формує нову виконавчу школу, яка вимагає від співаків додаткових професійних якостей.

Ключові слова: опера, вердіївська музична драма, виконавська школа, вокальна педагогіка, виконавський стиль.

Wang Tie. National performing tradition as basis of opera creativity of G. Verdi. In article national and performing sources, with allocation of questions of history and the theory of vocal performance and vocal pedagogics as fundamentals of opera poetics of G. Verdi are investigated. Verdi musical drama appears as a result of development of opera art of Italy of the 19th century that proves and forms new performing school, demanding from singers of additional professional qualities.

Keywords: opera, Verdi musical drama, performing school, vocal pedagogics, performing style.

Стаття надійщла до редакцї 18.05.2016

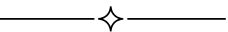

